\title{
GLOBAL SOURCING AND TECHNICAL EFFICIENCY - A FIRM-LEVEL STUDY ON THE ICT INDUSTRY IN SWEDEN
}

\author{
Martin ANDERSSON ${ }^{1}$, Trudy-Ann STONE ${ }^{2}$ \\ Blekinge Institute of Technology (BTH) and CIRCLE, Lund University, Sweden \\ E-mails: ${ }^{1}$ martin.andersson@bth.se; ${ }^{2}$ tas@bth.se (corresponding author)
}

Received 26 February 2017; accepted 13 July 2017

\begin{abstract}
We analyse the relationship between international sourcing, measured as imports of intermediate inputs, and the technical efficiency of firms in the information and communications technologies (ICT) manufacturing industry in Sweden. Using stochastic frontier analysis, we provide evidence that global sourcing improves firms' capabilities to combine and re-combine inputs in productive ways, thereby increasing technical efficiency. We find a robust relationship between technical efficiency and international outsourcing. First, we find that firms that are deeply integrated into global sourcing networks are closer to their own production frontier. Second, firms that are engaged in international sourcing are also closer to the industry efficiency frontier. These findings are consistent with the argument that international sourcing stimulates firms' capabilities by enabling them to identify and adopt higher quality inputs or more efficient production and management practices. These findings also suggest that the variety and extent of firms' global sourcing networks constitute an important source of differences in efficiency levels among firms the ICT manufacturing industry.
\end{abstract}

Keywords: technical efficiency, outsourcing, offshoring, globalization, variety, learning, recombinant capabilities, technology transfer, imports.

JEL Classification: D21, F61, L63, L23.

\section{Introduction}

International outsourcing has grown considerably in importance in recent decades. Falling trade and transportation costs in addition to advances in information and communications technology (ICT) enable firms to source production inputs globally and exploit global differences in comparative advantage across production stages. These trends leave clear footprints in global trade patterns. Hummels et al. (2001) show that vertical specialization - trade in intermediate goods that are imported and used to produce export goods - is a key feature of modern globalization. This is indicative of a wider trend of the global disintegration of production and is one of the main factors driving growth in world trade since the 1970s (Hummels et al. 2001).

Closely related to the growth in global sourcing is the evolution of the internal organization of firms. In many industries, firms no longer produce final goods along with 
all inputs to production that go into the manufacturing process, but rather modules that seamlessly integrate into a larger system. Aided by codification and standardization of tasks and routines, modular production systems are organized such that a good may be produced in stages by different firms (Baldwin, Clark 2000). For instance, the production process for a personal computer can today be described as modular, where computer design, chip production, operating systems and final assembly are performed by different firms (Dedrick et al. 2007). Modularity eliminates the need to specialize in all stages of the production chain, enabling firms to benefit from scale economies of their suppliers. It also gives rise to a greater degree of standardization, which ensures that firms can access the right components or inputs for their needs (Sturgeon 2002) ${ }^{1}$.

These developments have naturally led to an interest in the economic consequences of global sourcing and internationally fragmented production. Even though there are several arguments in favour of a positive effect of global sourcing on firms' performance, empirical evidence is limited and has so far produced rather mixed results (Bas, StraussKahn 2014; Lööf, Andersson 2010; Amiti, Konings 2007).

We contribute to the literature with a firm-level analysis of the influence that global sourcing has on firms' efficiency. Drawing on the international business literature as well as recent literature on the origins of firms' capabilities, we argue that global sourcing stimulates efficiency because it influences firms' capabilities to combine and re-combine inputs in productive ways (Elliot et al. 2016). That is, the extent to which global sourcing influences technical efficiency depends, at least in part, on how it influences capabilities that are specific to each firm. We put forth two main reasons for this.

The first is that exposure to, as well as interaction with, a foreign supplier may stimulate knowledge and information spillovers, which, in turn, enable firms to expand and improve their capabilities. The strategic management literature argues that heterogeneity in firm performance can be attributed to differences in firm capabilities, as firms vary in their ability to recombine resources to create new products or to address new problems (Mahmood et al. 2011; Dutta et al. 2005; Gulati et al. 2000). Capabilities refer to a firm's routines and internal coordination that enable it to "combine a number of resources [efficiently] to engage in productive activity and attain a certain objective" (Dutta et al. 2005: 278). Global sourcing can influence such capabilities because buyersupplier interaction induces knowledge transfer (van den Berg, van Marrewijk 2016; Mahmood et al. 2011; McEvily, Marcus 2005; Chetty, Holm 2000). For instance, such interaction may stimulate the identification and adoption of best practice in production processes and design, and put firms in a better position to identify "good" inputs that match their needs. Todo et al. (2016) find that that a more extensive and varied network of suppliers stimulates knowledge diffusion, which improves the buying firm's productivity and innovation capabilities.

\footnotetext{
${ }^{1}$ One of the earliest examples of a modular computer was the IBM System/360 (Baldwin, Henkel 2015; Ferguson, Morris 1993). The IBM System/360 was characterized by a high degree of flexibility so that devices such as disk drivers were interchangeable with other components. The IBM System/360 used a "mixed and matched catalog of peripheral equipment" (Ferguson, Morris 1993) so that an entire family of computers could share the same components and software.
} 
Our second argument is that engagement in global sourcing increases firms' incentives to develop their recombinant capabilities. The idea is that global sourcing may increase the modularity of firms' production systems, which, in turn, increases flexibility and enable combination of inputs in new ways. This enhances the returns, and hence incentives, to develop and strengthen recombinant capabilities. The interplay between modularity and returns to recombinant capabilities has been an important force determining the evolution of the computer industry. In the $1980 \mathrm{~s}$, new entrants to the computer industry were able to take advantage of modular design by imitating these individual modules or components to capture a significant share of the market. For instance, new firms, such as Compaq, were able to combine components from many different producers and erode the market share of the dominant firm, IBM (Baldwin, Henkel 2015; Ferguson, Morris 1993). One may thus argue that modularization raises the importance of recombinant capabilities.

To test these ideas, we employ Stochastic Frontier Analysis (SFA) to analyse the effects of global sourcing on firms' technical efficiency. The use of technical efficiency is motivated by the theoretical arguments linking global sourcing to firms' capabilities. Technical efficiency has in recent studies been used to quantify firms' capabilities (see Dutta et al. 2005, Mahmood et al. 2011). In these studies, capabilities are conceived of as "the efficiency with which a firm employs a given set of resources (inputs) at its disposal to achieve certain objectives (outputs)" (Dutta et al. 2005: 277). This is exactly what the technical efficiency of a firm aims to capture. Moreover, within industries, there tends to be a high degree of variation in firm performance, as not all firms achieve the maximum level of output attainable (Kumbhakar, Lovell 2000). Sources of such efficiency heterogeneity include differences in the way firms organize and manage their production, as well as differences in terms of firms' ability to match characteristics of their inputs to their needs. These examples of firm-level attributes ultimately reflect differences in "managerial capability".

Using data for firms in the Swedish ICT manufacturing industry, we analyse how the variety and the extent of firms' global sourcing network influence technical efficiency. We find a positive relationship between global sourcing and technical efficiency for firms in Swedish ICT manufacturing. This finding is consistent with the hypothesis that global sourcing improves firm-level technical efficiency, and puts firms in a better position to improve their capabilities.

\section{Data and variables}

We use audited full-population register data on Swedish firms that are maintained by Statistics Sweden $(\mathrm{SCB})^{2}$. This dataset includes information on firms' sales, capital expenditure, labour expenditure and value added. These data are complemented with individual-level register data, also obtained from SCB, which provide information on individuals' place of work and job classification. We use this matched employer-employee dataset to determine the skill-level of a firm's employees. In particular, we use

\footnotetext{
2 These data are accessed through SCB's microdata online access system. See http://www.scb.se/mona-en/
} 
four categories of workers when estimating the production frontier: knowledge workers, skilled workers, unskilled workers, and managers.

Finally, we complement our matched employer-employee dataset with firm-level trade data to measure each firm's level of participation in international trade. The data come from SCB and provide information each firm's total imports by product category, country of origin, the total value of each transaction in Swedish kronor and the volume (measured in kilograms) traded. We use the UN Broad Economic Categories to classify imports according to their end use. Summary statistics for all variables used in this analysis are provided in Table 1.

Table 1. Descriptive statistics for sample of ICT manufacturing firms with 10 or more employees

\begin{tabular}{lccccc}
\hline & Obs & Mean & Std. Dev. & Min & Max \\
\hline \hline Log(capital) & 1,523 & 14.714 & 1.873 & 7.902 & 21.558 \\
\hline Log(knowledge workers) & 1,523 & 1.056 & 1.415 & 0 & 8.983 \\
\hline Log(skilled workers) & 1,523 & 1.908 & 1.423 & 0 & 8.654 \\
\hline Log(unskilled workers) & 1,523 & 2.901 & 1.294 & 0 & 8.720 \\
\hline Log (managers) & 1,523 & 1.274 & 1.060 & 0 & 7.434 \\
\hline Log(No. of employees) & 1,523 & 3.592 & 1.132 & 2.303 & 9.916 \\
\hline High skilled/total workers & 1,523 & 0.348 & 0.229 & 0 & 1 \\
\hline Log (value added) & 1,523 & 16.827 & 1.342 & 11.898 & 24.117 \\
\hline \hline Time & 1,523 & 4.681 & 1.420 & 2 & 6 \\
\hline Year & 1,523 & 2005 & 1.709 & 2003 & 2008 \\
\hline Log (import value) & 1,523 & 13.769 & 4.908 & 0 & 23.539 \\
\hline No. of products imported & 1,523 & 61.779 & 123.949 & 0 & 1577 \\
\hline No. of source countries & 1,523 & 12.519 & 12.663 & 0 & 126 \\
\hline \hline Domestic firm & 1,523 & 0.396 & 0.489 & 0 & 1 \\
\hline Swedish MNE & 1,523 & 0.279 & 0.449 & 0 & 1 \\
\hline Foreign MNE & 1,523 & 0.194 & 0.395 & 0 & 1 \\
\hline Unaffiliated firm & 1,523 & 0.131 & 0.338 & 0 & 1 \\
\hline $10-50$ employees & 1,523 & 0.679 & 0.467 & 0 & 1 \\
\hline $51-250$ employees & 1,523 & 0.254 & 0.435 & 0 & 1 \\
\hline$>250$ employees & 1,523 & 0.067 & 9.250 & 0 & 1 \\
\hline \hline Herfindahl index (countries) & 1,523 & 0.513 & 0.282 & 0 & 0.936 \\
\hline Herfindahl index (products) & 1,523 & 0.426 & 0.290 & 0 & 0.970 \\
\hline Across country entropy & 1,523 & 0.160 & 0.132 & 0 & 0.368 \\
\hline Within country entropy & 1,523 & 0.873 & 1.582 & 0 & 16.707 \\
\hline Total entropy & 1,523 & 1.033 & 1.599 & 0 & 16.710 \\
\hline & & & & 0 & 0 \\
\hline
\end{tabular}

Note: The descriptive statistics are based on unbalanced panel firms in Swedish ICT manufacturing industry observed over a period of six years (2003-2008). 
Global sourcing patterns are calculated using several different measures of dispersion. First, we include count values for the number of countries a firm sources from as well as the number of products imported from each country. Our second measure of diversification, the Herfindahl index, is defined as the sum of the squared share of each product (country) in a firm's imports. The Herfindahl index ranges between zero and one, so that values close to zero indicate that the firm's imports are evenly distributed among many "small" products (countries). Large values (close to 1) suggest that the variety of inputs imported by a firm is dominated by a few main products (countries). One drawback of this measure is that firms that import just one product also have a high value for the Herfindahl index. We, therefore, specify the Herfindahl index as one minus the sum of squared shares so that large values correspond with greater diversification (Jacquemin, Berry 1979).

Our third measure, the entropy measure of diversification, accounts for the relative importance of each source country as well as the level of diversification at the product level. This can be expressed as:

$$
E_{T}=\sum_{i=1}^{n} P_{i} \ln 1 / P_{i}=\sum_{s=1}^{s} P_{s}\left(E_{W}\right)+E_{A}
$$

where $P_{i}$ denotes the share of product $i$ in a firm's total imports, $P_{S}$ represents the share of each source country $s$ in a firm's total imports. We follow the method proposed in Jacquemin and Berry (1979) to decompose the variety of channels through which a firm sources its inputs by taking into consideration the country and product dimensions. That is, we measure the dispersion of imports across source countries as well as the dispersion of imports across products within each source country. Total entropy is then decomposed into $E_{W}$ and $E_{A}$ to capture within- and across entropy-country, respectively. Here, we take advantage of the fact that we can disaggregate imports from country $s$ into imports of product $i$ from country $s$ to determine the relative contribution of diversification across countries and within countries to total entropy. Thus, within-country entropy measure is defined as:

$$
E_{W}=\sum_{i \in S} \frac{P_{i}}{P_{S}} \ln \frac{P_{S}}{P_{i}} .
$$

Finally, across country entropy is defined as the share of imports from country s multiplied by the log of the inverse, or:

$$
E_{A}=\sum_{s=1}^{S} \frac{P_{i}}{P_{S}} \ln \frac{1}{P_{S}} .
$$

The entropy measure is equal to zero if all imports are concentrated in one product or are sourced from just one country. Conversely, the measure is maximized when imports are evenly distributed across products and countries. Hence, we expect to find that firms vary in terms of their maximum entropy value and that this variation helps to explain variation in efficiency between firms. 


\subsection{Imports of intermediate inputs of ICT manufacturing firms in Sweden}

This subsection analyses and discusses the sourcing patterns of manufacturing firms in the ICT industry. While nearly all firms import some fraction of their intermediate inputs, the dispersion of imports varies across firms. Figure 1 shows the variation in the number of imported intermediate inputs among firms that import, and Figure 2 shows the same pattern for the number of source countries from which firms source inputs.

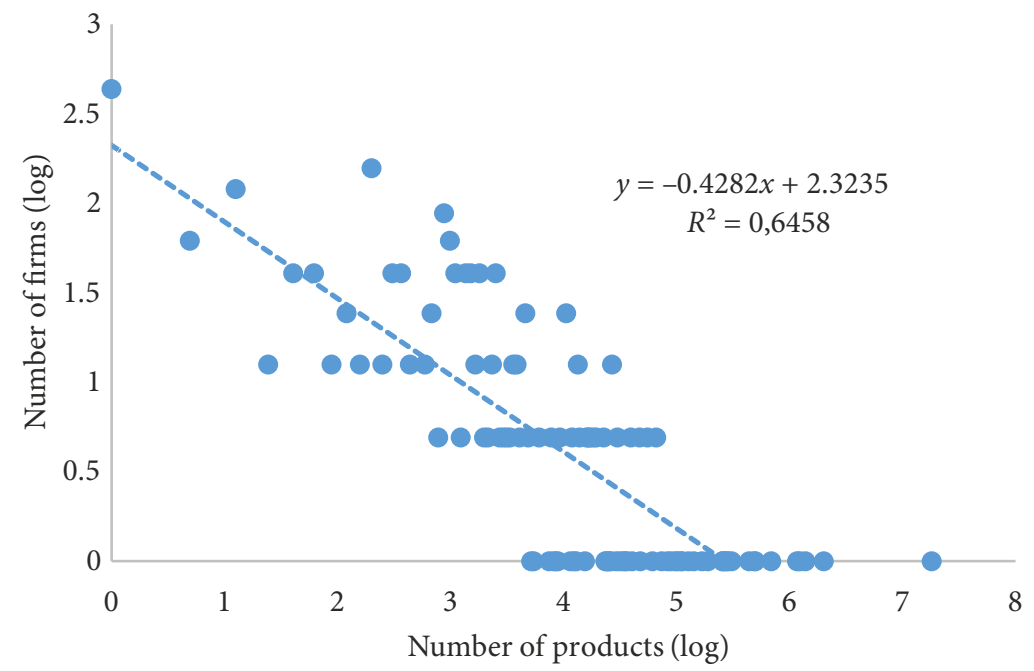

Fig. 1. Distribution of manufacturing firms in the ICT sector according to the number of intermediate inputs that firms import. In the figure a dot denotes the number of firms importing a given number of intermediate inputs Source: authors' calculation based on data from SCB.

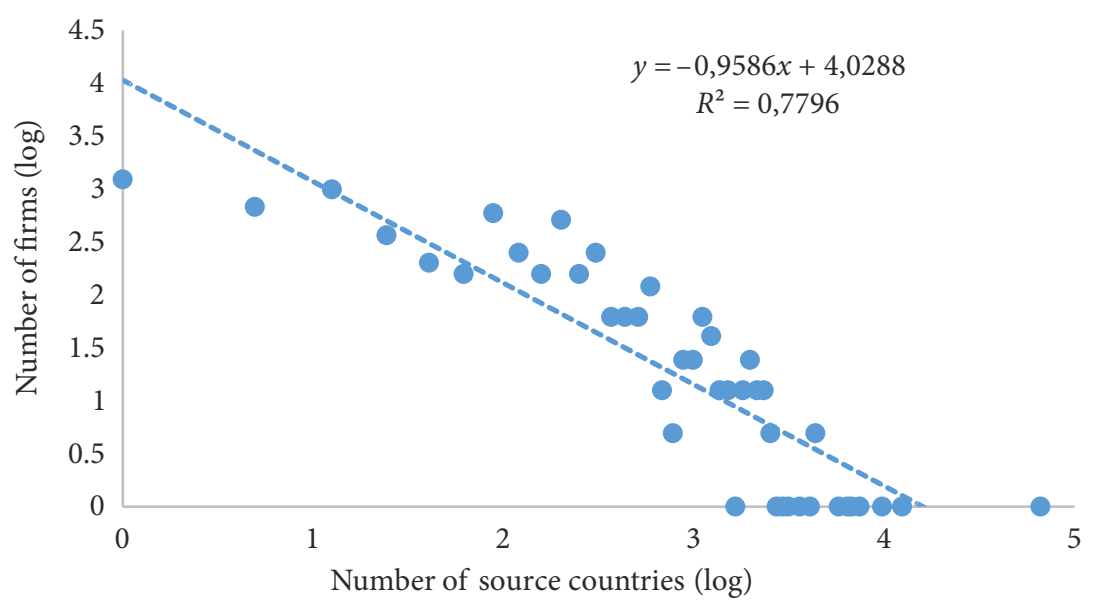

Fig. 2. Distribution of manufacturing firms in the ICT sector according to the number of source countries from which firms source inputs. In the figure a dot indicates the number of firms importing from a given number of source countries Source: authors' calculation based on data from SCB. 
It is clear from the figures that there is substantial heterogeneity across firms in terms of their sourcing pattern. Only a few firms source a large number of products from abroad. The same applies to the number of source countries - these patterns show that within the group of importing firms, the depth of firms' integration into the global economy varies substantially across firms. This finding is consistent with previous research on the patterns of internationalization among firms (Eaton et al. 2008; Andersson et al. 2008).

\section{Empirical strategy}

Stochastic Frontier Analysis has been widely used in the productivity and efficiency literature to measure firm performance relative to some benchmark (Aigner et al. 1977) 3 . It is a parametric approach used to estimate production frontier models, allowing for the fact that firms may not always make full use of their production inputs (Del Gatto et al. 2011). SFA estimates the efficiency level of a firm based on the deviation between a firm's output level and the maximum output attainable using a given set of inputs. Because this deviation reflects managers' capacity to utilize firms' resources efficiently, SFA can be used to analyse firms' capabilities (Dutta et al. 2005; Mahmood et al. 2011). Standard ways to measure productivity, such as total factor productivity (TFP), implicitly assume that all firms are technically efficient ${ }^{4}$ (Coelli et al. 2005). SFA enables us to relax this assumption and analyse the factors that explain why these differences in efficiency levels may arise.

Figure 3 illustrates how SFA can be used to estimate technical inefficiency by measuring the distance between a firm's output and the maximum output attainable given the

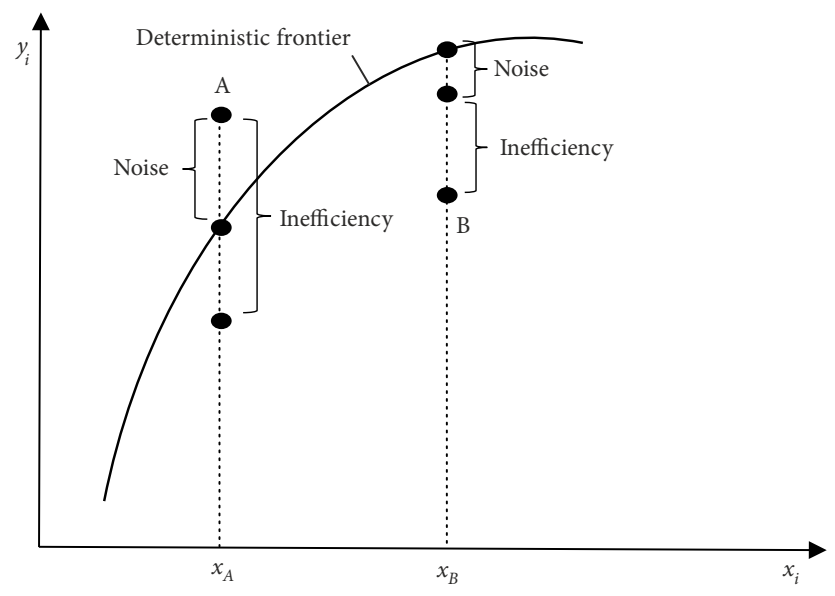

Fig. 3. The Stochastic Production Frontier

Source: adapted from Fried et al. (2008).

\footnotetext{
${ }^{3}$ For a review of various applications of Stochastic Frontier Analysis see Fried et al. (2008).

${ }^{4}$ However, empirical studies reveal that there is a wide disparity in firm performance, even within narrowly-defined industries (Syverson 2011).
} 
current level of inputs. A firm's output level may deviate from the deterministic frontier in two ways. At point $A$, the firm's output level lies above the frontier, but this deviation is due solely to the noise effect. In contrast, at point $B$, the output level lies below the frontier, and this deviation is attributed to both a noise component and an inefficiency component. The figure shows that by using SFA, a firm's performance is measured as the deviation from the frontier attributed to inefficiency while accounting for the deviation caused by firm-specific random shocks or noise.

We use SFA to estimate a firm-specific production frontier, from which each firm's level of inefficiency is computed. This means that a firm's inefficiency score is determined relative to its own frontier. In estimating the frontier, we use the Translog specification as it does not make assumptions on returns to scale in production, nor does it restrict elasticity of substitution or homotheticity. Our empirical implementation of SFA is given by:

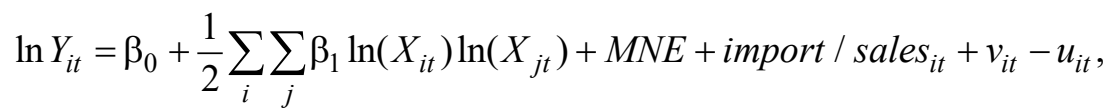

where we measure output $Y_{i t}$ as $\log$ value added. The variables $X_{i t}$ and $Y_{j t}$ represent factors of production - capital and four categories of labour described earlier. Our main variable of interest is the composite error term, $v_{i t}-u_{i t}$, where $u_{i t}$ represents technical inefficiency and $v_{i t}$ represents the "noise" term. By definition, the technical inefficiency term, $u_{i t}$, is nonnegative since it measures deviation from the production frontier. The random component of the composite error term, $v_{i t}$, is normally distributed independently of $u_{i t}$ and $X_{i t}$. To analyse the influence of global sourcing on technical efficiency, we use the time varying inefficiency model proposed by Battese and Coelli (1995) and estimate the following:

$$
u_{i t}=\delta_{1} \text { size }+\delta_{2} \text { skill }_{i t}+\delta_{3} \text { import_diversification }_{i t}+W_{i t},
$$

where the dependent variable, $u_{i t}$, refers to technical inefficiency. This model assumes that the inefficiency term follows a truncated normal distribution and allows us to estimate the frontier and the inefficiency term simultaneously. We can therefore determine the shape of the frontier term $y_{i t}$ and the inefficiency term $u_{i t}$ in one single step. Another key advantage of this model by Battese and Coelli (1995) is that it enables us to determine the effect of firm characteristics on mean inefficiency.

We estimate mean technical efficiency using the specification in Eq. (5), where $W_{i t}$ ensures than $u_{i t}$ remains nonnegative. Our main interest lies in the coefficient $\delta_{3}$, which measures the influence that our measures of global sourcing, represented by the variable import_diversification $_{i t}$, have on mean inefficiency. We expect to obtain a negative coefficient, indicating that global sourcing has a negative effect on inefficiency - or, stated otherwise, a positive effect on efficiency. We also control for a number of confounding factors such as firm size (size). Last, we include the variable skill $i t$ to control for the share of workers with more than three years' university education and account for the level of human capital in the firm.

A key issue for our empirical analysis concerns selection effects. Well-managed firms may be in a better position and have the resources needed to source globally. This 
implies that a positive association between efficiency and global sourcing could reflect such a selection effect - efficient firms source more inputs globally than inefficient ones - rather than the effect of global sourcing to firm-level efficiency.

We deal with this identification problem in two main ways. First, we specify the production frontier function in Eq. (4) such that it accounts for firm-specific characteristics that may influence its production frontier. This specification ensures that the estimation of each firm's production frontier accounts for relevant production characteristics of firms, and are not erroneously picked up as technical efficiency. We decompose labour into four categories: knowledge workers, skilled production workers, managerial workers, and unskilled workers. This decomposition allows us to capture the nature and human capital intensity of production. Specifically, human capital determines a firm's capacity to absorb and assimilate external knowledge to develop new capabilities, and may influence firms' production frontier (Cohen, Levinthal 1990; Bartel, Lichtenberg 1987).

To reflect differences in firms' internal resources, we also include a categorical variable for multinational status to account for the fact that individual firms belonging to company groups, and multinationals, in particular, may benefit from internal knowledge and technology resources as well as production routines. MNEs typically have links to several markets and knowledge sources (Dachs et al. 2007) and they tend to have strong internal capabilities to develop proprietary knowledge (Pfaffermayr, Bellak 2002), which may influence their production frontier. Time dummies are included to account for temporal shocks that may influence firms' production frontier.

Finally, we include import intensity, measured as total imports divided by total sales, directly in the estimation of the production frontier (Eq. (4)). Since firms that engage in international trade tend to be larger and more productive than other firms (Andersson et al. 2008; Wagner 2007; Bernard et al. 2007; Bernard, Wagner 1997), accounting for import intensity may capture characteristics of firms that directly influence their production frontier.

\subsection{Distance to the industry frontier}

In addition to analysing the influence that global sourcing has on a firm's efficiency relative to its own frontier, we also evaluate the contribution of a firm's sourcing strategy to its performance relative to the most efficient firm in the industry. The decision to import intermediate inputs is related to a firm's distance to the industry efficiency frontier. Acemoglu et al. (2007) find that the choice between vertical integration and more decentralized organizational forms depends on the firm's distance to the frontier. In particular, they show that three main characteristics influence whether firms' are more likely to be decentralized: young firms, firms that operate in more heterogeneous environments and firms that are closer to the technological frontier tend to have a more decentralized organizational structure. As the ICT manufacturing industry can be characterized as heterogeneous with many young firms (see Fig. 5), we therefore hypothesize that importing intermediate inputs improves a firm's performance, and induces convergence to the industry frontier. 
To this end, we compute the firm's efficiency level relative to the benchmark as a measure of the distance to the industry frontier and calculate:

$$
\operatorname{dist}_{i t}=\ln \left(\frac{u_{i t}^{*}}{u_{i t}}\right),
$$

where $u_{i t}^{*}$ represents the efficiency score for the benchmark firm. We then calculate the absolute value of the distance so that large values imply that firms are closer to the frontier. Using this distance to the frontier as our measure of relative efficiency, we estimate Eq. (6):

$$
\text { dist }_{i t}=\alpha+\beta_{1} \text { import }_{i t}+\beta_{2} \text { skill }_{i t}+\beta_{3} \text { size }+\mu_{t}+\varepsilon_{i t},
$$

where the dependent variable is our distance measure defined above. The right-hand side variables are the same as in Eq. (5), in which we analyse the influence of global sourcing, import $_{i t}$, as well as skill intensity, skill $_{i t}$, and a categorical variable to account for firm size. Our coefficient of interest is $\beta_{1}$, which captures the relationship between the extensive margin of imports and firms' distance to the industry frontier. We expect to find a negative relationship between import diversification and our distance measure. A negative and statistically significant value for each $\beta_{1}$ confirms our hypothesis that greater import diversification is associated with being closer to the industry frontier. That is, more efficient firms are more deeply integrated in international markets and source a greater range of inputs internationally.

\subsubsection{Trends in efficiency}

Before discussing our main results, we first examine broad patterns in firm efficiency levels between 2003 and 2008. Figure 4 plots the trend in mean efficiency for all firms in the industry and the efficiency level for the most efficient firm in each year. There is a steady increase in the average level of efficiency over the period, as mean efficiency levels increased from 0.66 to around 0.76 .

Additionally, the maximum efficiency score increased between 2004 and 2008, after declining slightly between 2003 and 2004, indicating an overall increase in efficiency level of the benchmark firm over this period. Figure 5 plots the estimated Kernel density of efficiency scores for the period 2003 to 2006. It is evident that the distribution has shifted to the right, indicating that firms in the ICT manufacturing industry have become more efficient. The figure also shows that the level of heterogeneity across the industry has decreased, as the spread of the distribution decreased in 2006 relative to 2003. 

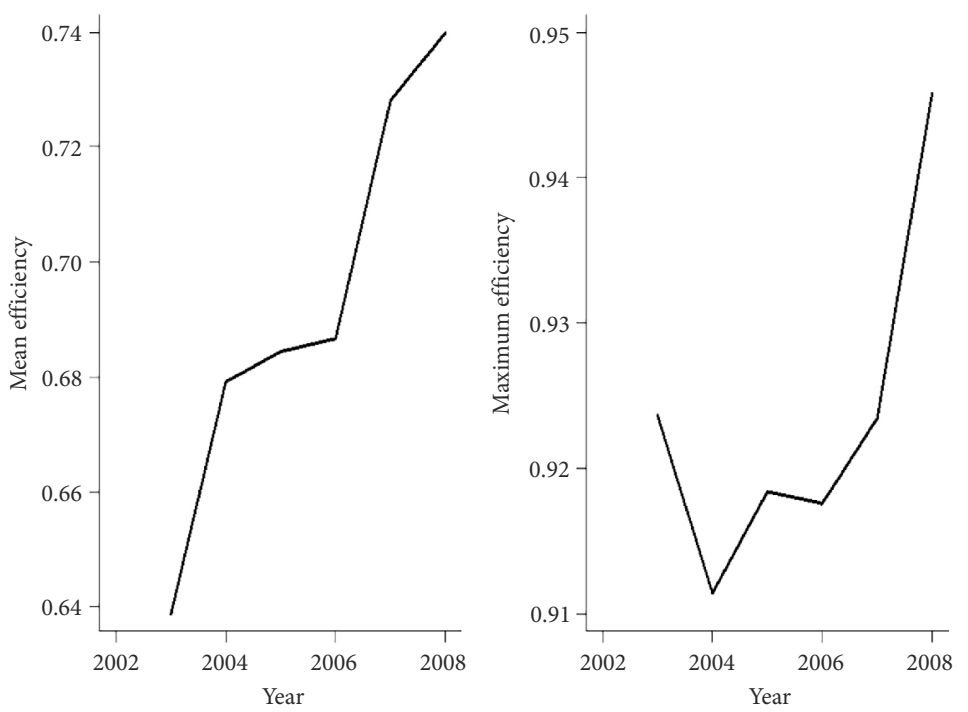

Fig. 4. Trends in mean efficiency and maximum efficiency (2003-2008)

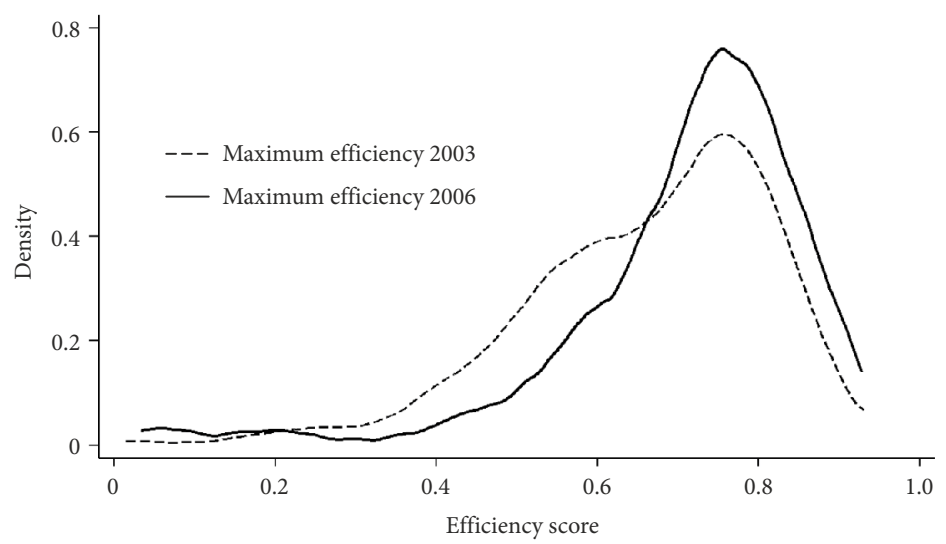

Fig. 5. Maximum efficiency for ICT manufacturing firms (2003-2006)

\section{Results}

We estimate the production frontier (given in Eq. (4)) and the mean inefficiency term in Eq. (5) simultaneously. Table 2 reports the results of Eq. (5) for each measure of global sourcing. The full results of the Translog estimation are presented in the Appendix ${ }^{5}$. Column 1 of Table 2 shows the results when we use the number of imported inputs as

\footnotetext{
${ }^{5}$ Since we cannot directly interpret the parameters of the Translog model, we calculate elasticities at mean values as the derivative of output (value added) with respect to each input. All estimated elasticities are positive, with the exception of the input category managers.
} 
our measure of global sourcing. We find a negative relationship between the number of inputs imported and the mean level of inefficiency. That is, importing intermediate inputs has a positive effect on mean efficiency. These results are in line with the idea that firms who import a wider variety of inputs may be more flexible in the way their production is organized. As a result, firms that are more deeply integrated into global value chains tend to be more efficient.

We also examine the role of import variety along another dimension: the breadth of countries from which firms import and find that the greater number of source countries, the higher the level of mean efficiency (Column 2). Firms that source a wider range of inputs from more source countries can exploit differences in comparative advantage across countries to gain access to the best quality inputs.

Table 2. The influence of global sourcing on firms' inefficiency

\begin{tabular}{|c|c|c|c|c|c|c|}
\hline Variables & (1) & (2) & (3) & (4) & (5) & (6) \\
\hline $\operatorname{Ln}$ (\# of inputs) & $\begin{array}{c}-0.617 * * * \\
(0.143)\end{array}$ & & & & & \\
\hline $\operatorname{Ln}(\#$ of countries) & & $\begin{array}{c}-0.733^{* * *} \\
(0.154)\end{array}$ & & & & \\
\hline HHI (countries) & & & $\begin{array}{c}-1.271 * * * \\
(0.339)\end{array}$ & & & \\
\hline HHI (products) & & & & $\begin{array}{c}-0.865 * * * \\
(0.300)\end{array}$ & & \\
\hline Total entropy & & & & & $\begin{array}{c}-0.142 * * * \\
(0.053)\end{array}$ & \\
\hline $\begin{array}{l}\text { Within country } \\
\text { entropy }\end{array}$ & & & & & & $\begin{array}{c}-0.137 * * \\
(0.054)\end{array}$ \\
\hline $\begin{array}{l}\text { Across country } \\
\text { entropy }\end{array}$ & & & & & & $\begin{array}{c}-0.873^{*} \\
(0.519)\end{array}$ \\
\hline $\begin{array}{l}\text { High skilled/total } \\
\text { workers }\end{array}$ & $\begin{array}{c}0.198 \\
(0.452)\end{array}$ & $\begin{array}{c}0.138 \\
(0.376)\end{array}$ & $\begin{array}{l}-0.302 \\
(0.351)\end{array}$ & $\begin{array}{c}-0.695^{*} \\
(0.382)\end{array}$ & $\begin{array}{c}-0.639^{*} \\
(0.337)\end{array}$ & $\begin{array}{c}-0.620^{*} \\
(0.359)\end{array}$ \\
\hline $\begin{array}{l}51-250 \\
\text { employees }\end{array}$ & $\begin{array}{l}-0.037 \\
(0.314)\end{array}$ & $\begin{array}{c}0.042 \\
(0.279)\end{array}$ & $\begin{array}{c}-0.377^{*} \\
(0.225)\end{array}$ & $\begin{array}{c}-0.605 * * * \\
(0.225)\end{array}$ & $\begin{array}{c}-0.605^{* * *} \\
(0.200)\end{array}$ & $\begin{array}{c}-0.644 * * * \\
(0.216)\end{array}$ \\
\hline$>250$ employees & $\begin{array}{l}-0.609 \\
(0.835)\end{array}$ & $\begin{array}{l}-0.256 \\
(0.654)\end{array}$ & $\begin{array}{l}-0.565 \\
(0.515)\end{array}$ & $\begin{array}{l}-0.797 \\
(0.509)\end{array}$ & $\begin{array}{c}-0.841^{*} \\
(0.441)\end{array}$ & $\begin{array}{c}-0.909^{*} \\
(0.473)\end{array}$ \\
\hline Obs. & 1,400 & 1,400 & 1,400 & 1,400 & 1,399 & 1,399 \\
\hline No. of firms & 360 & 360 & 360 & 360 & 360 & 360 \\
\hline
\end{tabular}

Note: The table reports estimate the influence of firm-level characteristics on firms' inefficiency using SFA. The underlying data are 360 firms in the ICT manufacturing industry in Sweden. Inefficiency scores are based on a Translog estimation of each firm's production frontier (see Eq. (4) and Eq. (5)). Results from this model are presented in Appendix. Standard errors in parentheses. $* * * p<0.01$, $* * \mathrm{p}<0.05, * \mathrm{p}<0.1$. 
So far our measures of import diversification amount to simple product and source country counts, which may not capture the full effect of global sourcing on efficiency levels. The Herfindahl index still shows that there is a strong negative relationship between greater import diversity and inefficiency. Using total entropy as a measure of import diversification, we obtain a negative and significant coefficient (Column 5). It is also clear that within and across country entropy measures are negatively associated with inefficiency. This further indicates that global sourcing is associated with better technical efficiency.

Turning to the control variables, we see that medium-sized firms with 51-250 employees are most efficient. The relationship between firm size and efficiency is often not clear-cut. One argument is that larger firms should be more efficient since they can take advantage of economies of scale and produce a higher level of output more cheaply. However, production processes are often very complex, and there might be other factors at play that are idiosyncratic to larger firms that make them less efficient. Our findings are similar to Castiglione (2012), who finds that medium-sized firms in the Italian manufacturing sector are more efficient than large firms. Human capital, measured as the fraction of employees with at least three years' university education, is statistically insignificant in the first three specifications but negative and significant in columns 4, 5 and 6 of Table 2 . These results indicate that firms with an educated workforce are more efficient, which is in line with our expectations.

\subsection{Global sourcing and distance to the industry frontier}

We now show results from an estimation of Eq. (7), which allow us to assess whether differences in firms' sourcing behaviour are related to differences in relative firm-level efficiencies. Table 3 shows the effect of imports on heterogeneity in the ICT industry. Starting with the control variables, we see that firms with a greater fraction of highskilled employees have a smaller distance to the most efficient firm in the industry. It is also clear that medium-sized as well as large firms show a smaller gap to the industry frontier. Both results are in line with expectations.

Turning to the variables of interest, Column 1 reveals that there is a negative relationship between import variety using the Herfindahl index along the product dimension and the distance to the industry frontier. This indicates that the more diversified a firm's imports, the lower the distance to the industry frontier. However, we do not find that the relationship is statistically significant.

We repeat the analysis using other measures of import variety. These include total diversification using the Herfindahl index, the number of products, the number of source countries, and our entropy measure of diversification. Column 2 shows that there is a negative and statistically significant relationship between import diversification and distance to the industry frontier. These results hold when we use count measures of diversification: importing a higher number of products from a wider range of countries is associated with better performance relative to the most efficient firm. This confirms our hypothesis that being deeply integrated into the global value chain augurs well for a firm's performance level. 
Table 3. Global sourcing and distance to the industry frontier

\begin{tabular}{|c|c|c|c|c|c|c|}
\hline Variables & (1) & (2) & (3) & (4) & (5) & (6) \\
\hline HHI (products) & $\begin{array}{l}-0.011 \\
(0.049)\end{array}$ & & & & & \\
\hline HHI (countries) & & $\begin{array}{c}-0.155^{* * *} \\
(0.053)\end{array}$ & & & & \\
\hline Ln (no. inputs) & & & $\begin{array}{c}-0.054 * * * \\
(0.013)\end{array}$ & & & \\
\hline $\begin{array}{l}\text { Ln (no. source } \\
\text { countries) }\end{array}$ & & & & $\begin{array}{c}-0.090^{* * * *} \\
(0.017)\end{array}$ & & \\
\hline $\begin{array}{l}\text { Across country } \\
\text { entropy }\end{array}$ & & & & & $\begin{array}{l}-0.025 \\
(0.105)\end{array}$ & \\
\hline $\begin{array}{l}\text { Within country } \\
\text { entropy }\end{array}$ & & & & & $\begin{array}{l}-0.011 \\
(0.009)\end{array}$ & \\
\hline Total entropy & & & & & & $\begin{array}{l}-0.011 \\
(0.009)\end{array}$ \\
\hline $\begin{array}{l}\text { High skilled/total } \\
\text { workers }\end{array}$ & $\begin{array}{c}-0.348^{* * *} \\
(0.071)\end{array}$ & $\begin{array}{c}-0.312 * * * \\
(0.072)\end{array}$ & $\begin{array}{c}-0.300 * * * \\
(0.073)\end{array}$ & $\begin{array}{c}-0.270^{* * * *} \\
(0.074)\end{array}$ & $\begin{array}{c}-0.346^{* * *} \\
(0.071)\end{array}$ & $\begin{array}{c}-0.346 * * * \\
(0.071)\end{array}$ \\
\hline $\begin{array}{l}51-250 \\
\text { employees }\end{array}$ & $\begin{array}{c}-0.261 * * * \\
(0.033)\end{array}$ & $\begin{array}{c}-0.223 * * * \\
(0.034)\end{array}$ & $\begin{array}{c}-0.178 * * * \\
(0.039)\end{array}$ & $\begin{array}{c}-0.156^{* * * *} \\
(0.037)\end{array}$ & $\begin{array}{c}-0.267 * * * \\
(0.032)\end{array}$ & $\begin{array}{c}-0.267 * * * \\
(0.032)\end{array}$ \\
\hline$>250$ employees & $\begin{array}{c}-0.375^{* * *} \\
(0.063)\end{array}$ & $\begin{array}{c}-0.332 * * * \\
(0.063)\end{array}$ & $\begin{array}{c}-0.236^{* * * *} \\
(0.073)\end{array}$ & $\begin{array}{c}-0.226^{* * * *} \\
(0.070)\end{array}$ & $\begin{array}{c}-0.382 * * * \\
(0.061)\end{array}$ & $\begin{array}{c}-0.382 * * * \\
(0.061)\end{array}$ \\
\hline Observations & 1,400 & 1,400 & 1,400 & 1,400 & 1,399 & 1,399 \\
\hline Number of firms & 360 & 360 & 360 & 360 & 360 & 360 \\
\hline
\end{tabular}

Note: The reports estimate on the influence of firm-level characteristics on relative efficiency (see Eq. (7)). The underlying data are 360 firms in the ICT manufacturing industry in Sweden. Inefficiencies are based on a Translog estimation of each firm's production frontier (see Eq. (4) and Eq. (5)). Results from this model are presented in Appendix. The estimations include time dummies. Standard errors in parentheses. $* * * \mathrm{p}<0.01, * * \mathrm{p}<0.05, * \mathrm{p}<0.1$.

In Column 6, we present the estimation results of Eq. (7), in which we measure the variety of a firm's imports using total entropy. We find that there is a negative relationship between our entropy variable and distance to the frontier. In Column 5, we decompose entropy into its constituent parts - across- and within-country entropy. The results are similar to our previous findings when total entropy is used as our measure of import diversification. However, while the direction of the relationship and the size of the coefficient are similar to other measures of diversification, using entropy does not yield statistically significant results. We interpret these results as follows. Taken together, our results show that global sourcing has a strong impact on within-firm performance. Our results also show that importing a larger number of inputs puts firms in a position to improve their efficiency levels relative to the benchmark firm. Nevertheless, our entropy measure reveals that the effect of global sourcing on intra-industry heterogeneity may be more involved. 


\section{Conclusions}

This paper has examined how sourcing production inputs globally influences the performance of ICT manufacturing firms in Sweden, focusing on technical efficiency. Our main argument is that the influence of global sourcing on technical efficiency is not a mechanical one. Instead, the extent to which a firm becomes more efficient as a result of global sourcing depends, at least in part, on its internal capabilities. Using SFA, we test this idea by estimating how the extent of firms' global sourcing networks influences technical efficiency.

The main conclusion of this paper is that a strategy to source globally puts firms in a better position to improve their capabilities. We find that firms that are more involved in sourcing and have a more diversified import network are indeed more efficient than their peers. These results hold across all measures of import diversification. This is consistent with the argument that global sourcing is not only about exploiting cost differences across countries, which provides firms with "static" gains from cost reductions. A more extensive import network (involving a wide variety of foreign suppliers) appears to improve the potential for knowledge and information spillovers.

This paper contributes to the growing literature emphasizing global import networks as important sources of productivity growth. We make us of detailed data on the import networks of each firm and show that the benefits of global sourcing go beyond one-time cost reductions; instead, firms may continue to derive benefits from internationalization through dynamic performance improvements. Secondly, our paper highlights how global sourcing influences the internal organization of firms. In particular, using SFA we show that recombinant capabilities allow firms to use imported inputs to achieve novel or more efficient ways to expand output.

Our research relies on the use of confidential microdata on the entire population of Swedish firms. While this leads to more generalizable results, using register data constrains our ability to determine the specific mechanism through which global sourcing enables firms to derive efficiency improvements. In this respect, future research could unpack the sources of efficiency gains through global sourcing by analysing how firms in international supply networks interact with each other. Also, understanding the types of inter-firm relationships that stimulate knowledge transfer and promote efficiency improvement is another possible avenue for future research.

\section{References}

Acemoglu, D.; Aghion, P.; Lelarge, C.; Van Reenen, J.; Zilibotti, F. 2007. Technology, information, and the decentralization of the firm, Quarterly Journal of Economics 122(4): 1759-1799. https://doi.org/10.1162/qjec.2007.122.4.1759

Aigner, D.; Lovell, C.; Schmidt, P. 1977. Formulation and estimation of stochastic frontier production function models, Journal of Econometrics 6(1): 21-37.

https://doi.org/10.1016/0304-4076(77)90052-5

Amiti, M.; Konings, J. 2007. Trade liberalization, intermediate inputs, and productivity: evidence from Indonesia, American Economic Review 97(5): 1611-1638.

https://doi.org/10.1257/aer.97.5.1611 
Andersson, M.; Lööf, H.; Johansson, S. 2008. Productivity and international trade: firm level evidence from a small open economy, Review of World Economics 144(4): 774-801.

https://doi.org/10.1007/s10290-008-0169-5

Baldwin, C.; Clark, K. B. 2000. Design rules, Vol. 1: The power of modularity. Cambridge, MA: MIT Press.

Baldwin, C.; Henkel, J. 2015. Modularity and intellectual property protection, Strategic Management Journal 36(11): 1637-1655. https://doi.org/10.1002/smj.2303

Bartel, A.; Lichtenberg, F. 1987. The comparative advantage of educated workers in implementing new technology, Review of Economics and Statistics 69(1): 1-11. https://doi.org/10.2307/1937894

Bas, M.; Strauss-Kahn, V. 2014. Does importing more inputs raise exports? Firm-level evidence from France, Review of World Economics 150(2): 241-275.

https://doi.org/10.1007/s10290-013-0175-0

Battese, G.; Coelli, T. 1995. A model for technical inefficiency effects in a stochastic frontier production function for Panel Data, Empirical Economics 20(2): 325-332.

https://doi.org/10.1007/BF01205442

Bernard, A. B.; Jensen, J. B.; Redding, S.; Schott, P. K. 2007. Firms in international trade, Journal of Economic Perspectives 21(3): 105-130. https://doi.org/10.1257/jep.21.3.105

Bernard, A.; Wagner, J. 1997. Exports and success in German manufacturing, Weltwirtschaft Archiv 133(1): 134-157. https://doi.org/10.1007/BF02707680

Castiglione, C. 2012. Technical efficiency and ICT investment in Italian manufacturing firms, Applied Economics 44(14): 1749-1763. https://doi.org/10.1080/00036846.2011.554374

Chetty, S.; Holm, D. 2000. Internationalisation of small to medium-sized manufacturing firms: a network approach, International Business Review 9(1): 77-93.

https://doi.org/10.1016/S0969-5931(99)00030-X

Coelli, T. J.; Rao, D. S. P.; O’Donnell, C. J.; Battese, G. E. 2005. An introduction to efficiency and productivity analysis. Springer Science \& Business Media.

Cohen, W.; Levinthal, D. 1990. Absorptive capacity: a new perspective on learning and innovation, Administrative Science Quarterly 35(1): 128-152. https://doi.org/10.2307/2393553

Dachs, B.; Ebersberger, B.; Lööf, H. 2008. The innovative performance of foreign-owned enterprises in small open economies, Journal of Technology Transfer 33(4): 393-406.

https://doi.org/10.1007/s10961-007-9058-7

Dedrick, J.; Kraemer, K.; Linden, G.; Brown, C.; Murtha, T. 2007. Organizing lobal knowledge networks in the electronics industry. Working Paper [online], [cited 03 June 2015]. Personal Computing Industry Center: UC Irvine. Available from Internet: http://escholarship.org/ uc/item/5267284q

Del Gatto, M.; Di Liberto, A.; Petraglia, C. 2011. Measuring productivity, Journal of Economic Surveys 25(5): 952-1008. https://doi.org/10.1111/j.1467-6419.2009.00620.x

Dutta, S.; Narasimhan, O.; Rajiv, S. 2005. Conceptualizing and measuring capabilities: methodology and empirical application, Strategic Management Journal 26(3): 277-285.

https://doi.org/10.1002/smj.442

Eaton, J.; Kortum, S.; Kramarz, F. 2011. An anatomy of international trade: evidence from French firms, Econometrica 79(5): 389-405.

Elliott, R.; Jabbour, L.; Zhang, L. 2016. Firm productivity and importing: evidence from Chinese manufacturing firms, Canadian Journal of Economics 49(3): 1086-1124.

https://doi.org/10.1111/caje.12226

Ferguson, C.; Morris, C. 1993. Computer wars: how the West can win in a post-IBM world. Times Books. 
Fried, H.; Lovell, C.; Schmidt, S. 2008. Efficiency and productivity, in The measurement of productive efficiency and productivity growth. Oxford University Press.

https://doi.org/10.1093/acprof:oso/9780195183528.001.0001

Gulati, R.; Nohria, N.; Zaheer, A. 2000. Strategic networks, Strategic Management Journal 21(3): 203-215. https://doi.org/10.1002/(SICI)1097-0266(200003)21:3<203::AID-SMJ102>3.0.CO;2-K

Hummels, D.; Ishii, J.; Yi, K.-M. 2001. The nature and growth of vertical specialization in world trade, Journal of International Economics 54(1): 75-96.

https://doi.org/10.1016/S0022-1996(00)00093-3

Jacquemin, A. P.; Berry, C. H. 1979. Entropy measure of diversification and corporate growth, Journal of Industrial Economics 27(4): 359-369. https://doi.org/10.2307/2097958

Kumbhakar, S.; Lovell, C. 2003. Stochastic frontier analysis. Cambridge: Cambridge University Press.

Lööf, H.; Andersson, M. 2010. Imports, productivity and origin markets: the role of knowledgeintensive economies, The World Economy 33(3): 458-481.

https://doi.org/10.1111/j.1467-9701.2010.01263.x

Mahmood, I.; Hongjin, Z.; Zajac, E. 2011. Where can capabilities come from? Network ties and capability acquisition in business groups, Strategic Management Journal 32(8): 820-828.

https://doi.org/10.1002/smj.911

McEvily, B.; Marcus, A. 2005. Embedded ties and the acquisition of competitive capabilities, Strategic Management Journal 26(11): 1033-1055. https://doi.org/10.1002/smj.484

Pfaffermayr, M.; Bellak, C. 2002. Why foreign-owned firms are different: a conceptual framework and empirical evidence for Austria, Chapter 2, in R. Jungnickel (Ed.). Foreign-owned firms. London: Palgrave Macmillan. https://doi.org/10.1057/9780230503434_2

Sturgeon, T. 2002. Modular production networks: a new American model of industrial organization, Industrial and Corporate Change 11(3): 451-496. https://doi.org/10.1093/icc/11.3.451

Syverson, C. 2011. What determines productivity?, Journal of Economic Literature 49(2): 32665. https://doi.org/10.1257/jel.49.2.326

Todo, Y.; Matous, P.; Inoue, H. 2016. The strength of long ties and the weakness of strong ties: knowledge diffusion through supply chain networks, Research Policy 45(9): 1890-1906.

https://doi.org/10.1016/j.respol.2016.06.008

van den Berg, M.; van Marrewijk, C. 2016. Imports and productivity: the impact of geography and factor intensity, The Journal of International Trade \& Economic Development 26(4): 425-450. https://doi.org/10.1080/09638199.2016.1263359

Wagner, J. 2007. Exports and productivity: a survey of the evidence from firm-level data, The World Economy 30(1): 60-82. https://doi.org/10.1111/j.1467-9701.2007.00872.x 


\section{Appendix}

Production frontier esimates using stochastic frontier analysis

\begin{tabular}{|c|c|c|c|c|c|c|c|c|}
\hline Variables & (1) & (2) & (3) & (4) & (5) & (6) & (7) & (8) \\
\hline Ln (capital) & $\begin{array}{c}0.500^{* * *} \\
(0.154)\end{array}$ & $\begin{array}{c}-0.464 * * * \\
(0.154)\end{array}$ & $\begin{array}{c}-0.417 * * * \\
(0.153)\end{array}$ & $\begin{array}{c}-0.408^{* * *} \\
(0.153)\end{array}$ & $\begin{array}{c}-0.385^{* *} \\
(0.152)\end{array}$ & $\begin{array}{c}-0.397 * * * \\
(0.152)\end{array}$ & $\begin{array}{c}-0.458^{* * *} \\
(0.154)\end{array}$ & $\begin{aligned} &-0.508 * * * \\
&(0.154)\end{aligned}$ \\
\hline $\begin{array}{l}\text { Ln (knowledge } \\
\text { workers) }\end{array}$ & $\begin{array}{c}0.596^{* * *} \\
(0.146)\end{array}$ & $\begin{array}{c}0.575 * * * \\
(0.146)\end{array}$ & $\begin{array}{c}0.536^{* * *} \\
(0.147)\end{array}$ & $\begin{array}{c}0.513 * * * \\
(0.147)\end{array}$ & $\begin{array}{c}0.504 * * * \\
(0.147)\end{array}$ & $\begin{array}{c}0.512 * * * \\
(0.147)\end{array}$ & $\begin{array}{c}0.576^{* * *} \\
(0.146)\end{array}$ & $\begin{array}{c}0.596^{* * * *} \\
(0.146)\end{array}$ \\
\hline $\begin{array}{l}\text { Ln (skilled } \\
\text { workers) }\end{array}$ & $\begin{array}{c}0.678^{* * *} \\
(0.145)\end{array}$ & $\begin{array}{c}0.669^{* * *} \\
(0.146)\end{array}$ & $\begin{array}{c}0.643 * * * \\
(0.147)\end{array}$ & $\begin{array}{c}0.654 * * * \\
(0.147)\end{array}$ & $\begin{array}{c}0.633^{* * * *} \\
(0.146)\end{array}$ & $\begin{array}{c}0.637 * * * \\
(0.146)\end{array}$ & $\begin{array}{c}0.667 * * * \\
(0.145)\end{array}$ & $\begin{array}{c}0.686^{* * * *} \\
(0.145)\end{array}$ \\
\hline $\begin{array}{l}\text { Ln (unskilled } \\
\text { workers) }\end{array}$ & $\begin{array}{c}0.427 * * \\
(0.172)\end{array}$ & $\begin{array}{l}0.393^{* *} \\
(0.171)\end{array}$ & $\begin{array}{c}0.350^{* *} \\
(0.170)\end{array}$ & $\begin{array}{c}0.357^{* *} \\
(0.169)\end{array}$ & $\begin{array}{l}0.376^{* *} \\
(0.168)\end{array}$ & $\begin{array}{c}0.379 * * \\
(0.168)\end{array}$ & $\begin{array}{c}0.405^{* *} \\
(0.171)\end{array}$ & $\begin{array}{c}0.424 * * \\
(0.172)\end{array}$ \\
\hline $\begin{array}{l}\mathrm{Ln} \text { (man } \\
\text { workers) }\end{array}$ & $\begin{array}{c}-0.651^{* * *} \\
(0.194)\end{array}$ & $\begin{aligned} &-0.689 * * * \\
&(0.194)\end{aligned}$ & $\begin{array}{c}-0.641 * * * \\
(0.194)\end{array}$ & $\begin{array}{l}-0.599 * * * \\
(0.195)\end{array}$ & $\begin{array}{c}-0.576^{* * *} \\
(0.195)\end{array}$ & $\begin{array}{c}-0.569 * * * \\
(0.195)\end{array}$ & $\begin{array}{c}-0.699 * * * \\
(0.194)\end{array}$ & $\begin{aligned} &-0.642 * * * \\
&(0.195)\end{aligned}$ \\
\hline Time dummy & $\begin{array}{c}0.153 \\
(0.123)\end{array}$ & $\begin{array}{c}0.131 \\
(0.124)\end{array}$ & $\begin{array}{c}0.189 \\
(0.124)\end{array}$ & $\begin{array}{l}0.217^{*} \\
(0.123)\end{array}$ & $\begin{array}{l}0.216^{*} \\
(0.123)\end{array}$ & $\begin{array}{c}0.202 \\
(0.124)\end{array}$ & $\begin{array}{c}0.128 \\
(0.124)\end{array}$ & $\begin{array}{c}0.153 \\
(0.123)\end{array}$ \\
\hline $\begin{array}{l}\text { Capital x } \\
\text { knowledge } \\
\text { workers }\end{array}$ & $\begin{array}{c}-0.026^{* *} \\
(0.011)\end{array}$ & $\begin{array}{c}-0.024 * * \\
(0.011)\end{array}$ & $\begin{array}{l}-0.022^{*} \\
(0.011)\end{array}$ & $\begin{array}{c}-0.021^{*} \\
(0.011)\end{array}$ & $\begin{array}{c}-0.020^{*} \\
(0.011)\end{array}$ & $\begin{array}{c}-0.021^{*} \\
(0.011)\end{array}$ & $\begin{array}{c}-0.024 * * \\
(0.011)\end{array}$ & $\begin{array}{c}-0.026^{* *} \\
(0.011)\end{array}$ \\
\hline $\begin{array}{l}\text { Capital x } \\
\text { skilled workers }\end{array}$ & $\begin{array}{c}-0.019^{*} \\
(0.011)\end{array}$ & $\begin{array}{c}-0.019^{*} \\
(0.011)\end{array}$ & $\begin{array}{l}-0.018 \\
(0.011)\end{array}$ & $\begin{array}{l}-0.018 \\
(0.011)\end{array}$ & $\begin{array}{l}-0.015 \\
(0.011)\end{array}$ & $\begin{array}{l}-0.016 \\
(0.011)\end{array}$ & $\begin{array}{c}-0.019^{*} \\
(0.011)\end{array}$ & $\begin{array}{c}-0.020^{*} \\
(0.011)\end{array}$ \\
\hline $\begin{array}{l}\text { Capital x } \\
\text { unskilled } \\
\text { workers }\end{array}$ & $\begin{array}{l}-0.013 \\
(0.013)\end{array}$ & $\begin{array}{l}-0.012 \\
(0.013)\end{array}$ & $\begin{array}{l}-0.008 \\
(0.013)\end{array}$ & $\begin{array}{l}-0.006 \\
(0.013)\end{array}$ & $\begin{array}{l}-0.006 \\
(0.013)\end{array}$ & $\begin{array}{l}-0.007 \\
(0.013)\end{array}$ & $\begin{array}{l}-0.012 \\
(0.013)\end{array}$ & $\begin{array}{l}-0.013 \\
(0.013)\end{array}$ \\
\hline $\begin{array}{l}\text { Capital x } \\
\text { managers }\end{array}$ & $\begin{array}{c}0.051^{* * * *} \\
(0.015)\end{array}$ & $\begin{array}{c}0.054 * * * \\
(0.015)\end{array}$ & $\begin{array}{c}0.051 * * * \\
(0.016)\end{array}$ & $\begin{array}{c}0.045 * * * \\
(0.016)\end{array}$ & $\begin{array}{c}0.043 * * * \\
(0.016)\end{array}$ & $\begin{array}{c}0.043 * * * \\
(0.016)\end{array}$ & $\begin{array}{c}0.054 * * * \\
(0.015)\end{array}$ & $\begin{array}{c}0.051 * * * \\
(0.015)\end{array}$ \\
\hline $\begin{array}{l}\text { Knowledge } \\
\text { workers X } \\
\text { skilled workers }\end{array}$ & $\begin{array}{c}0.019 \\
(0.013)\end{array}$ & $\begin{array}{c}0.019 \\
(0.013)\end{array}$ & $\begin{array}{l}0.023^{*} \\
(0.014)\end{array}$ & $\begin{array}{l}0.025^{*} \\
(0.013)\end{array}$ & $\begin{array}{l}0.027^{* *} \\
(0.013)\end{array}$ & $\begin{array}{c}0.027 * * \\
(0.013)\end{array}$ & $\begin{array}{c}0.019 \\
(0.013)\end{array}$ & $\begin{array}{c}0.018 \\
(0.013)\end{array}$ \\
\hline $\begin{array}{l}\text { Knowledge } \\
\text { workers X } \\
\text { unskilled } \\
\text { workers }\end{array}$ & $\begin{array}{c}-0.063 * * * \\
(0.015)\end{array}$ & $\begin{aligned} &-0.064 * * * \\
&(0.015)\end{aligned}$ & $\begin{array}{c}-0.064 * * * \\
(0.016)\end{array}$ & $\begin{array}{l}-0.065^{* * *} \\
(0.015)\end{array}$ & $\begin{array}{c}-0.067 * * * \\
(0.016)\end{array}$ & $\begin{array}{c}-0.067 * * * \\
(0.016)\end{array}$ & $\begin{array}{c}-0.065^{* * *} \\
(0.015)\end{array}$ & $\begin{aligned} &-0.063 * * * \\
&(0.015)\end{aligned}$ \\
\hline $\begin{array}{l}\text { Knowledge } \\
\text { workers } \mathrm{x} \\
\text { managers }\end{array}$ & $\begin{array}{c}0.023 \\
(0.018)\end{array}$ & $\begin{array}{c}0.021 \\
(0.018)\end{array}$ & $\begin{array}{c}0.021 \\
(0.018)\end{array}$ & $\begin{array}{c}0.021 \\
(0.018)\end{array}$ & $\begin{array}{c}0.021 \\
(0.018)\end{array}$ & $\begin{array}{c}0.022 \\
(0.018)\end{array}$ & $\begin{array}{c}0.021 \\
(0.018)\end{array}$ & $\begin{array}{c}0.023 \\
(0.018)\end{array}$ \\
\hline $\begin{array}{l}\text { Skilled workers } \\
\text { x unskilled } \\
\text { workers }\end{array}$ & $\begin{array}{c}-0.085 * * * \\
(0.017)\end{array}$ & $\begin{aligned} &-0.084 * * * \\
&(0.017)\end{aligned}$ & $\begin{array}{c}-0.087 * * * \\
(0.017)\end{array}$ & $\begin{array}{c}-0.090^{* * *} \\
(0.017)\end{array}$ & $\begin{array}{c}-0.092 * * * \\
(0.017)\end{array}$ & $\begin{array}{c}-0.092 * * * \\
(0.017)\end{array}$ & $\begin{array}{c}-0.083 * * * \\
(0.017)\end{array}$ & $\begin{array}{c}-0.085 * * * \\
(0.017)\end{array}$ \\
\hline $\begin{array}{l}\text { Skilled workers } \\
\mathrm{x} \text { managers }\end{array}$ & $\begin{array}{c}-0.118^{* * *} \\
(0.018)\end{array}$ & $\begin{array}{c}-0.119 * * * \\
(0.019)\end{array}$ & $\begin{array}{c}-0.119 * * * \\
(0.019)\end{array}$ & $\begin{array}{c}-0.116^{* * *} \\
(0.019)\end{array}$ & $\begin{array}{c}-0.119 * * * \\
(0.019)\end{array}$ & $\begin{aligned} &-0.119 * * * \\
&(0.018)\end{aligned}$ & $\begin{array}{c}-0.119 * * * \\
(0.019)\end{array}$ & $\begin{array}{c}-0.117 * * * \\
(0.018)\end{array}$ \\
\hline $\begin{array}{l}\text { Unskilled } \\
\text { workers x } \\
\text { managers }\end{array}$ & $\begin{array}{l}-0.018 \\
(0.021)\end{array}$ & $\begin{array}{l}-0.017 \\
(0.021)\end{array}$ & $\begin{array}{l}-0.014 \\
(0.021)\end{array}$ & $\begin{array}{l}-0.014 \\
(0.021)\end{array}$ & $\begin{array}{l}-0.003 \\
(0.021)\end{array}$ & $\begin{array}{l}-0.003 \\
(0.021)\end{array}$ & $\begin{array}{l}-0.016 \\
(0.021)\end{array}$ & $\begin{array}{l}-0.019 \\
(0.021)\end{array}$ \\
\hline
\end{tabular}


Continue of Appendix

\begin{tabular}{|c|c|c|c|c|c|c|c|c|}
\hline Variables & (1) & (2) & (3) & (4) & (5) & (6) & (7) & (8) \\
\hline Capital x time & $\begin{array}{c}0.001 \\
(0.008)\end{array}$ & $\begin{array}{c}0.003 \\
(0.008)\end{array}$ & $\begin{array}{c}0.001 \\
(0.008)\end{array}$ & $\begin{array}{l}-0.001 \\
(0.008)\end{array}$ & $\begin{array}{c}0.000 \\
(0.008)\end{array}$ & $\begin{array}{c}0.001 \\
(0.008)\end{array}$ & $\begin{array}{c}0.003 \\
(0.008)\end{array}$ & $\begin{array}{c}0.001 \\
(0.008)\end{array}$ \\
\hline $\begin{array}{l}\text { Knowledge } \\
\text { workers x time }\end{array}$ & $\begin{array}{c}0.004 \\
(0.009)\end{array}$ & $\begin{array}{c}0.002 \\
(0.009)\end{array}$ & $\begin{array}{c}0.002 \\
(0.009)\end{array}$ & $\begin{array}{c}0.002 \\
(0.009)\end{array}$ & $\begin{array}{c}0.003 \\
(0.009)\end{array}$ & $\begin{array}{c}0.003 \\
(0.009)\end{array}$ & $\begin{array}{c}0.002 \\
(0.009)\end{array}$ & $\begin{array}{c}0.003 \\
(0.009)\end{array}$ \\
\hline $\begin{array}{l}\text { Skilled workers } \\
\text { x time }\end{array}$ & $\begin{array}{c}-0.028^{* * *} . \\
(0.010)\end{array}$ & $\begin{array}{c}-0.029 * * * \\
(0.010)\end{array}$ & $\begin{array}{c}-0.027 * * * \\
(0.010)\end{array}$ & $\begin{array}{c}-0.026^{* * *} \\
(0.010)\end{array}$ & $\begin{array}{c}-0.026^{* * *} \\
(0.010)\end{array}$ & $\begin{array}{c}-0.026^{* * *} \\
(0.010)\end{array}$ & $\begin{array}{c}-0.029 * * * \\
(0.010)\end{array}$ & $\begin{array}{c}-0.027^{* * * *} \\
(0.010)\end{array}$ \\
\hline $\begin{array}{l}\text { Unskilled } \\
\text { workers } \mathrm{x} \text { time }\end{array}$ & $\begin{array}{l}-0.018 \\
(0.011)\end{array}$ & $\begin{array}{l}-0.016 \\
(0.011)\end{array}$ & $\begin{array}{l}-0.016 \\
(0.011)\end{array}$ & $\begin{array}{c}-0.020^{*} \\
(0.011)\end{array}$ & $\begin{array}{c}-0.022 * * \\
(0.011)\end{array}$ & $\begin{array}{c}-0.022 * * \\
(0.011)\end{array}$ & $\begin{array}{l}-0.017 \\
(0.011)\end{array}$ & $\begin{array}{l}-0.018 \\
(0.011)\end{array}$ \\
\hline $\begin{array}{l}\text { Managers } x \\
\text { time }\end{array}$ & $\begin{array}{c}0.052 * * * \\
(0.015)\end{array}$ & $\begin{array}{c}0.051 * * * \\
(0.015)\end{array}$ & $\begin{array}{c}0.050^{* * * *} \\
(0.015)\end{array}$ & $\begin{array}{c}0.055^{* * *} \\
(0.015)\end{array}$ & $\begin{array}{c}0.055^{* * * *} \\
(0.015)\end{array}$ & $\begin{array}{c}0.053^{* * *} \\
(0.015)\end{array}$ & $\begin{array}{c}0.053^{* * *} \\
(0.015)\end{array}$ & $\begin{array}{c}0.052 * * * \\
(0.015)\end{array}$ \\
\hline Capital` $^{\wedge}$ & $\begin{array}{c}0.042 * * * \\
(0.012)\end{array}$ & $\begin{array}{c}0.038 * * * \\
(0.012)\end{array}$ & $\begin{array}{c}0.034 * * * \\
(0.012)\end{array}$ & $\begin{array}{c}0.034 * * * \\
(0.012)\end{array}$ & $\begin{array}{c}0.032 * * * \\
(0.012)\end{array}$ & $\begin{array}{c}0.033^{* * *} \\
(0.012)\end{array}$ & $\begin{array}{c}0.037 * * * \\
(0.012)\end{array}$ & $\begin{array}{c}0.042 * * * \\
(0.012)\end{array}$ \\
\hline $\begin{array}{l}\text { Knowledge } \\
\text { workers ^ } 2\end{array}$ & $\begin{array}{c}0.066^{* * * *} \\
(0.019)\end{array}$ & $\begin{array}{c}0.065^{* * * *} \\
(0.020)\end{array}$ & $\begin{array}{c}0.059 * * * \\
(0.020)\end{array}$ & $\begin{array}{c}0.057 * * * \\
(0.020)\end{array}$ & $\begin{array}{c}0.055 * * * \\
(0.020)\end{array}$ & $\begin{array}{c}0.055^{* * *} \\
(0.020)\end{array}$ & $\begin{array}{c}0.066^{* * * *} \\
(0.020)\end{array}$ & $\begin{array}{c}0.066^{* * *} \\
(0.019)\end{array}$ \\
\hline $\begin{array}{l}\text { Skilled workers } \\
{ }^{\wedge} 2\end{array}$ & $\begin{array}{c}0.163^{* * *} \\
(0.020)\end{array}$ & $\begin{array}{c}0.167 * * * \\
(0.020)\end{array}$ & $\begin{array}{c}0.167 * * * \\
(0.020)\end{array}$ & $\begin{array}{c}0.162 * * * \\
(0.020)\end{array}$ & $\begin{array}{c}0.159^{* * * *} \\
(0.020)\end{array}$ & $\begin{array}{c}0.161^{* * *} \\
(0.020)\end{array}$ & $\begin{array}{c}0.165^{* * *} \\
(0.020)\end{array}$ & $\begin{array}{c}0.164 * * * \\
(0.020)\end{array}$ \\
\hline $\begin{array}{l}\text { Unskilled } \\
\text { workers }{ }^{\wedge} 2\end{array}$ & $\begin{array}{c}0.166 * * * \\
(0.023)\end{array}$ & $\begin{array}{c}0.164 * * * \\
(0.023)\end{array}$ & $\begin{array}{c}0.162 * * * \\
(0.023)\end{array}$ & $\begin{array}{c}0.159 * * * \\
(0.023)\end{array}$ & $\begin{array}{c}0.156^{* * * *} \\
(0.023)\end{array}$ & $\begin{array}{c}0.158^{* * *} \\
(0.023)\end{array}$ & $\begin{array}{c}0.163 * * * \\
(0.023)\end{array}$ & $\begin{array}{c}0.167^{* * *} \\
(0.023)\end{array}$ \\
\hline Managers $` 2$ & $\begin{array}{c}0.070^{* *} \\
(0.032)\end{array}$ & $\begin{array}{c}0.063 * * \\
(0.031)\end{array}$ & $\begin{array}{c}0.064 * * \\
(0.030)\end{array}$ & $\begin{array}{c}0.073 * * \\
(0.030)\end{array}$ & $\begin{array}{c}0.068^{* *} \\
(0.029)\end{array}$ & $\begin{array}{l}0.068^{* *} \\
(0.030)\end{array}$ & $\begin{array}{c}0.064^{* *} \\
(0.030)\end{array}$ & $\begin{array}{c}0.072 * * \\
(0.032)\end{array}$ \\
\hline Time $^{\wedge} 2$ & $\begin{array}{c}-0.031^{*} \\
(0.016)\end{array}$ & $\begin{array}{c}-0.033^{* *} \\
(0.017)\end{array}$ & $\begin{array}{c}-0.038^{* *} \\
(0.017)\end{array}$ & $\begin{array}{c}-0.039^{* *} \\
(0.017)\end{array}$ & $\begin{array}{c}-0.040 * * \\
(0.017)\end{array}$ & $\begin{array}{c}-0.040^{* *} \\
(0.017)\end{array}$ & $\begin{array}{c}-0.033^{* *} \\
(0.017)\end{array}$ & $\begin{array}{c}-0.031^{*} \\
(0.016)\end{array}$ \\
\hline Swedish MNE & $\begin{array}{c}0.129 * * * \\
(0.034)\end{array}$ & $\begin{array}{c}0.122 * * * \\
(0.034)\end{array}$ & $\begin{array}{c}0.123 * * * \\
(0.034)\end{array}$ & $\begin{array}{c}0.131 * * * \\
(0.035)\end{array}$ & $\begin{array}{c}0.123 * * * \\
(0.035)\end{array}$ & $\begin{array}{c}0.125^{* * *} \\
(0.035)\end{array}$ & $\begin{array}{c}0.122 * * * \\
(0.034)\end{array}$ & $\begin{array}{c}0.131^{* * * *} \\
(0.034)\end{array}$ \\
\hline Foreign MNE & $\begin{array}{c}0.179 * * * \\
(0.037)\end{array}$ & $\begin{array}{c}0.171 * * * \\
(0.037)\end{array}$ & $\begin{array}{c}0.186 * * * \\
(0.039)\end{array}$ & $\begin{array}{c}0.194 * * * \\
(0.039)\end{array}$ & $\begin{array}{c}0.190 * * * \\
(0.039)\end{array}$ & $\begin{array}{c}0.192 * * * \\
(0.039)\end{array}$ & $\begin{array}{c}0.168 * * * \\
(0.037)\end{array}$ & $\begin{array}{c}0.181^{* * * *} \\
(0.037)\end{array}$ \\
\hline $\begin{array}{l}\text { Unaffiliated } \\
\text { firm }\end{array}$ & $\begin{array}{c}-0.088^{*} \\
(0.048)\end{array}$ & $\begin{array}{c}-0.080^{*} \\
(0.048)\end{array}$ & $\begin{array}{c}-0.101^{* *} \\
(0.048)\end{array}$ & $\begin{array}{c}-0.119 * * \\
(0.047)\end{array}$ & $\begin{array}{c}-0.121 * * \\
(0.047)\end{array}$ & $\begin{array}{c}-0.119^{* *} \\
(0.047)\end{array}$ & $\begin{array}{l}-0.077 \\
(0.049)\end{array}$ & $\begin{array}{c}-0.092 * \\
(0.047)\end{array}$ \\
\hline $\begin{array}{l}\text { Import } \\
\text { intensity }\end{array}$ & $\begin{array}{c}-0.165^{* * *} \\
(0.054)\end{array}$ & $\begin{array}{c}-0.167 * * * \\
(0.054)\end{array}$ & $\begin{array}{c}-0.112^{*} \\
(0.059)\end{array}$ & $\begin{array}{l}-0.105^{*} \\
(0.059)\end{array}$ & $\begin{array}{c}-0.117 * * \\
(0.059)\end{array}$ & $\begin{array}{l}-0.111^{*} \\
(0.059)\end{array}$ & $\begin{array}{c}-0.180 * * * \\
(0.054)\end{array}$ & $\begin{array}{c}-0.159 * * * \\
(0.054)\end{array}$ \\
\hline Constant & $\begin{array}{c}17.633^{* * *} \\
(1.088)\end{array}$ & $\begin{array}{c}17.530^{* * * *} \\
(1.089)\end{array}$ & $\begin{array}{c}17.160^{* * *} \\
(1.082)\end{array}$ & $\begin{array}{c}16.981 * * * \\
(1.080)\end{array}$ & $\begin{array}{c}16.813^{* * *} \\
(1.072)\end{array}$ & $\begin{array}{c}16.909 * * * \\
(1.074)\end{array}$ & $\begin{array}{c}17.490 * * * \\
(1.091)\end{array}$ & $\begin{array}{c}17.675^{* * * *} \\
(1.088)\end{array}$ \\
\hline \multicolumn{9}{|c|}{ Mean inefficiency } \\
\hline $\begin{array}{l}\text { Ln(number of } \\
\text { inputs) }\end{array}$ & $\begin{array}{c}-0.617 * * * \\
(0.143)\end{array}$ & & & & & & & $\begin{array}{c}-0.617^{* * * *} \\
(0.144)\end{array}$ \\
\hline $\begin{array}{l}\text { Ln(number } \\
\text { of source } \\
\text { countries) }\end{array}$ & & $\begin{array}{c}-0.733 * * * \\
(0.154)\end{array}$ & & & & & $\begin{array}{c}-0.919 * * * \\
(0.203)\end{array}$ & \\
\hline HHI & & & $\begin{array}{c}-1.271 * * * \\
(0.339)\end{array}$ & & & & $\begin{array}{l}0.820^{*} \\
(0.486)\end{array}$ & \\
\hline
\end{tabular}


End of Appendix

\begin{tabular}{|c|c|c|c|c|c|c|c|c|}
\hline Variables & (1) & (2) & (3) & (4) & (5) & (6) & (7) & (8) \\
\hline HHI (products) & & & & $\begin{array}{c}-0.865^{* * *} \\
(0.300)\end{array}$ & & & & $\begin{array}{l}-0.398 \\
(0.405)\end{array}$ \\
\hline Total entropy & & & & & $\begin{array}{c}-0.142 * * * \\
(0.053)\end{array}$ & & & \\
\hline $\begin{array}{l}\text { Within country } \\
\text { entropy }\end{array}$ & & & & & & $\begin{array}{c}-0.137 * * \\
(0.054)\end{array}$ & & \\
\hline $\begin{array}{l}\text { Across country } \\
\text { entropy }\end{array}$ & & & & & & $\begin{array}{c}-0.873^{*} \\
(0.519)\end{array}$ & & \\
\hline $\begin{array}{l}\text { Share of high } \\
\text { skilled workers }\end{array}$ & $\begin{array}{c}0.198 \\
(0.452)\end{array}$ & $\begin{array}{c}0.138 \\
(0.376)\end{array}$ & $\begin{array}{l}-0.302 \\
(0.351)\end{array}$ & $\begin{array}{c}-0.695^{*} \\
(0.382)\end{array}$ & $\begin{array}{c}-0.639^{*} \\
(0.337)\end{array}$ & $\begin{array}{l}-0.620^{*} \\
(0.359)\end{array}$ & $\begin{array}{c}0.122 \\
(0.369)\end{array}$ & $\begin{array}{c}0.187 \\
(0.477)\end{array}$ \\
\hline $\begin{array}{l}51-250 \\
\text { employees }\end{array}$ & $\begin{array}{l}-0.037 \\
(0.314)\end{array}$ & $\begin{array}{c}0.042 \\
(0.279)\end{array}$ & $\begin{array}{c}-0.377^{*} \\
(0.225)\end{array}$ & $\begin{array}{c}-0.605 * * * \\
(0.225)\end{array}$ & $\begin{array}{c}-0.605^{* * *} \\
(0.200)\end{array}$ & $\begin{array}{c}0.644 * * * \\
(0.216)\end{array}$ & $\begin{array}{c}0.060 \\
(0.274)\end{array}$ & $\begin{array}{l}-0.041 \\
(0.332)\end{array}$ \\
\hline $\begin{array}{l}>250 \\
\text { employees }\end{array}$ & $\begin{array}{l}-0.609 \\
(0.835)\end{array}$ & $\begin{array}{l}-0.256 \\
(0.654)\end{array}$ & $\begin{array}{l}-0.565 \\
(0.515)\end{array}$ & $\begin{array}{l}-0.797 \\
(0.509)\end{array}$ & $\begin{array}{c}-0.841^{*} \\
(0.441)\end{array}$ & $\begin{array}{l}-0.909^{*} \\
(0.473)\end{array}$ & $\begin{array}{l}-0.233 \\
(0.648)\end{array}$ & $\begin{array}{l}-0.623 \\
(0.859)\end{array}$ \\
\hline Observations & 1,400 & 1,400 & 1,400 & 1,400 & 1,399 & 1,399 & 1,400 & 1,400 \\
\hline $\begin{array}{l}\text { Number of } \\
\text { orgnr }\end{array}$ & 360 & 360 & 360 & 360 & 360 & 360 & 360 & 360 \\
\hline lambda & 2.974 & 2.765 & 2.491 & 2.446 & 2.295 & 2.371 & 2.738 & 3.049 \\
\hline sigma_u & 1.010 & 0.933 & 0.841 & 0.830 & 0.777 & 0.803 & 0.923 & 1.038 \\
\hline sigma_v & 0.340 & 0.337 & 0.338 & 0.339 & 0.339 & 0.339 & 0.337 & 0.340 \\
\hline Mean & 0.397 & 0.409 & 0.428 & 0.429 & 0.441 & 0.434 & 0.410 & 0.393 \\
\hline $\mathrm{SD}$ & 0.348 & 0.348 & 0.341 & 0.337 & 0.334 & 0.335 & 0.348 & 0.348 \\
\hline Min & 0.0552 & 0.0565 & 0.0573 & 0.0589 & 0.0552 & 0.0548 & 0.0568 & 0.0554 \\
\hline Max & 4.543 & 4.537 & 4.418 & 4.419 & 4.329 & 4.337 & 4.538 & 4.568 \\
\hline 11 & -972.5 & -973.9 & -992.9 & -998.4 & -998.2 & -997 & -972.4 & -972 \\
\hline chi2 & 6829 & 6370 & 5679 & 5823 & 5601 & 5700 & 6422 & 6927 \\
\hline $\mathrm{N}$ & 1400 & 1400 & 1400 & 1400 & 1399 & 1399 & 1400 & 1400 \\
\hline
\end{tabular}

Note: Standard errors in parentheses $* * * \mathrm{p}<0.01, * * \mathrm{p}<0.05, * \mathrm{p}<0.1$

Martin ANDERSSON is professor of Industrial Economics at Blekinge Institute of Technology (BTH) in Karlskrona, Sweden as well as professor of Innovation Studies at CIRCLE, Lund University. He is also affiliated to the Research Institute of Industrial Economics and the Swedish Entrepreneurship Forum in Stockholm. He has a PhD in Economics from Jönköping International Business School (JIBS).

Trudy-Ann STONE is a Lecturer in the Department of Urban Studies at Malmö University in Malmö Sweden. She has a PhD in Industrial Economics and Management from Blekinge Institute of Technology. 